\title{
Effects of chemical and physical characteristics of forage on dry-matter intake of cattle
}

\author{
J Sekine, J Ueda, J Hai, HEM Kamel, R Oura, Z Morita \\ Dept of Vet Sci, Fac of Agric, Tottori Univ, Tottori 680, Japan
}

To find simple but effective indices to predict forage intake, effects of chemical and physical characteristics of forage on the intake and the eating and ruminating behaviour were studied on such 8 kinds of forages as alfalfa hay $(A L)$, Italian ryegrass hay (IR), perennial ryegrass hay (PR), timothy hay (TI), bermudagrass hay $(B G)$, sudangrass hay (SG), oats hay $(\mathrm{OH})$ and rice straw (RS). Chemical compositions studied were neutral detergent fiber (NDF), acid detergent lignin (ADL) and crude protein (CP). Physical characteristics measured were as follows ; 1) the brittleness with abrasion (BBM) determined by the ratio of mean particle size of samples between before and after grinding with planet ball mill, 2) the brittleness with cutting (BCM) determined by the same method as BBM by grinding with a cutting mixer, 3) the dry bulk density (DBD, $\mathrm{g} / \mathrm{ml}$ ) determined with particle sizes of $1,2,4$ and $8 \mathrm{~mm}, 4)$ mass base surface areas $\left(S M_{p}, m^{2} / g\right)$ by a per- meameter and 5) mass base surface areas by the nitrogen gas adsorption method $\left(S_{N}\right.$, $\mathrm{m}^{2} / \mathrm{g}$ ). Dry-matter intake was measured by 8 Japanese Black cows under ad libitum feeding of 8 kinds of forage as a sole feed given in a sequential manner. The eating and ruminating behaviour was recorded for 24 hours by using the videorecorder with a time display from which total time spent for the behaviour was determined. Dry-matter intake (DMI, $\mathrm{g} / \mathrm{kg}^{0.75}$ ) was positively correlated with DBD $(P<0.01)$, and negatively with NDF content, $\mathrm{SM}_{p}$ and $S_{N}(P<0.05)$. Time spent for eating and ruminating ( $\mathrm{min} / \mathrm{DMI})$ was also negatively correlated with DMI $(P<0.01)$. Other characteristics of forage showed no significant correlation with DMI. DBD was negatively correlated with NDF content, $\mathrm{SM}_{\mathrm{P}}$ and $\mathrm{SM}_{\mathrm{N}}$, or time spent for eating and ruminating $(P<0.05)$.

DBD is inferred to be a possible index to predict forage intake for cattle.

\begin{tabular}{|c|c|c|c|c|c|c|c|c|c|c|}
\hline Forage & BBM & BCM & $\begin{array}{c}\text { DBD, } 4 \mathrm{~mm} \\
\mathrm{~g} / \mathrm{ml}\end{array}$ & $\begin{array}{l}\mathrm{SM}_{\mathrm{P}} \\
\mathrm{m}^{2 / g}\end{array}$ & $\begin{array}{l}\mathrm{SM}_{N} \\
\mathrm{~m}^{2 / g}\end{array}$ & $\begin{array}{c}\text { CP } \\
\% \mathrm{DM}\end{array}$ & $\begin{array}{l}\text { NDF } \\
\% D M\end{array}$ & $\begin{array}{l}\text { ADL } \\
\% D M\end{array}$ & $\begin{array}{c}\text { DMl } \\
\mathrm{g} / \mathrm{kg}^{0.75}\end{array}$ & $\begin{array}{c}\mathrm{R}^{1} \\
\mathrm{~min} / \mathrm{DMI}\end{array}$ \\
\hline AL & 0.46 & 0.33 & 0.293 & 0.058 & 0.61 & 14.7 & 48.1 & 7.5 & $113^{\mathrm{a} 2}$ & $3.3^{e}$ \\
\hline IR & 0.47 & 0.29 & 0.193 & 0.110 & 0.95 & 7.5 & 71.5 & 4.8 & $71^{\text {de }}$ & $6.2^{b}$ \\
\hline PR & 0.47 & 0.40 & 0.210 & 0.071 & 0.82 & 5.7 & 70.5 & 4.9 & $73^{\text {de }}$ & $7.5^{\mathrm{a}}$ \\
\hline $\mathrm{TI}$ & 0.71 & 0.38 & 0.260 & 0.067 & 0.49 & 4.5 & 67.6 & 5.8 & $101 a b$ & $4.4^{c}$ \\
\hline$B G$ & 0.66 & 0.33 & 0.214 & 0.081 & 0.54 & 9.7 & 68.4 & 3.5 & $83^{\mathrm{cd}}$ & $4.8^{c}$ \\
\hline$S G$ & 0.40 & 0.45 & 0.225 & 0.094 & 0.65 & 8.9 & 72.4 & 4.3 & $94 \mathrm{bc}$ & $4.3^{\circ}$ \\
\hline $\mathrm{OH}$ & 0.61 & 0.26 & 0.253 & 0.074 & 0.41 & 6.2 & 62.9 & 4.3 & $103^{a b}$ & $4.8^{c}$ \\
\hline RS & 0.27 & 0.45 & 0.178 & 0.123 & 1.06 & 3.7 & 76.9 & 3.8 & $67 \mathrm{e}$ & $6.4^{\mathrm{b}}$ \\
\hline
\end{tabular}

$1 R$ represents time spent for ruminating on the basis of dry-matter intake.

2 Figures in the same column with different superscripts differ significantly $(P<0.05)$. 